\title{
Antimicrobial Activity of Ultrasonic Extracts of Two Chemotypes of Thymus serpyllum L. of Central Kazakhstan and their Polyphenolic Profiles
}

Svetlana Ivasenko*, Perizat Orazbayeva1, Krystyna Skalicka-Wozniak², Agnieszka Ludwiczuk², Alexandr Marchenko ${ }^{2}$, Margarita Ishmuratova ${ }^{4}$, Ewa Poleszak ${ }^{5}$, Izabela Korona-Glowniak ${ }^{6}$, Saule Akhmetova ${ }^{7}$, Islambek Karilkhan ${ }^{7}$, Irina Loseva ${ }^{1}$

${ }^{1}$ Department of Pharmaceutical Disciplines and Chemistry, Karaganda Medical University, Karaganda, Kazakhstan; ${ }^{2}$ Department of Pharmacognosy, Medicinal Plant Unit, Medical University of Lublin, Lublin, Poland; ${ }^{3}$ Laboratory of Scientific and Research Center, Karaganda Medical University, Karaganda, Kazakhstan; ${ }^{4}$ Department of Pharmaceutical Disciplines, Academy "Bolashak," Karaganda, Kazakhstan; ${ }^{5}$ Department of Applied Pharmacy, Medical University of Lublin, Lublin, Poland; ${ }^{6}$ Department of Pharmaceutical Microbiology, Laboratory for Microbiological Diagnostics, Medical University of Lublin, Lublin, Poland; ' ${ }^{7}$ Department of Clinical Immunology, Allergology and Microbiology, Karaganda Medical University, Karaganda, Kazakhstan

Edited by: Sinisa Stojanosk Citation: Ivasenko S, Orazbayeva P, Skalicka-Wozniak K, Ludwiczuk A, Marchenko A, Ishmuratova M, Poleszak E, Korona-Glowniak I, Akhmetova S, Karilkhan I, Loseva I. Antimicrobial Activity of Ultrasonic Extracts of Two Chemotypes of Thymus serpyllum L. of Centra Maced J Med Sci. 2021 Jano5: 9(A):61-67. On Access org/10.3889/oamims. 2021 : 5520
Maced JMed Sci. 2021 Jan 05; llum L : Chemotypes: 2021.5520 $\begin{aligned} \text { Keywords: Thymus serpyllum L.; Chemotypes; Ultrasonic } & \text { extracts; Antimicrobial activity } \\ & \text { *Correspondence: Svetlana Ivasenko, Department }\end{aligned}$ Correspondence: Svetlana Ivasenko, Department
of Pharmaceutical Disciplines and Chemistry, Karaganda Medical University, Karaganda, Kazakhstan, -mail: Ivasenko@qmu.kz Received: 19-Oct-2020 Revised: 19-Dec-2020 Copyright: $\odot 2021$ Svethan Copyright: 2021 Svilana lvasenko erizat Orazbayeva, Krystyna Skalicka-Wozniak Agnieszka Ludwiczuk, Alexandr Marchenko, Izabela Korona-Glowniak, Saule Akhmetova, Islambek Karilkhan, Irina Loseva

Funding: This work was fully supported by grant of raganda Medical University (Decision of the Academic Council of KMU dated 23.06.2016., chief: S. Ivasenko) Competing Interests: The authors have declared that no competing interests exist

Open Access: This is an openacess atcle dist exted under the terms of the Creative Commons Attribution-

\section{Abstract}

BACKGROUND: The medicinal plant of Thymus serpyllum L. in nature, depending on the geographical region, climatic conditions, and growing environment, is represented with some chemotypes. Composition and quantitative content of the basic groups of the biologically active substances can be differed, and thus their biological properties are also various.

AIM: The aim of the study was to determine possibility of the using the ultrasonic extracts of two chemotypes of T. serpyllum L. of Central Kazakhstan as an antimicrobial agent against test strains of microorganisms.

MATERIALS AND METHODS: Two samples of $T$. serpyllum were extracted with $70 \%$ ethanol using ultrasound. The polyphenol content of the ultrasound extracts was determined using the LC-ultraviolet-ESI- tandem mass spectrometry technique. A study of an antimicrobial activity of the ultrasonic extracts was performed with eight strains of Gram-positive bacteria, six strains of Gram-negative bacteria, and four cultures of fungi.

RESULTS: The ultrasonic extracts of two chemotypes of $T$. serpyllum $L$. are similar in composition of phenolic compounds but differ in a quantitative content of phenolic acids and flavonoids, except for a rosmarinic acid. The ultrasonic extracts have a wide spectrum of antimicrobial activity, exhibit the bactericidal or bacteriostatic activity against all tested bacteria and fungi at a concentration of $0.0625-20 \mathrm{mg} / \mathrm{ml}$, but differ in their strength of action against test strains of microorganisms.

CONCLUSION: The ultrasonic extracts of two chemotypes of $T$. serpyllum L. of Central Kazakhstan can be considered as a potential drug with a wide spectrum of antimicrobial activity. The results of chromatographic analysis will be used for standardization of a drug.

\section{Introduction}

Thymus serpyllum L. (creeping thyme, thyme) is a perennial shrub, Eurasian species, grows in the temperate climate of Eurasia, from Scandinavia to the Mediterranean and from the British Isles to Eastern Siberia.

The medicinal properties of $T$. serpyllum L. herb are known since ancient times and for many centuries used in traditional and folk medicine all over the world. T. serpyllum L. herb is included in the State Pharmacopoeia of the Republic of Kazakhstan, the Russian Federation, Ukraine, and other countries, in official medicine used as a medicinal plant material with the antibacterial, astringent, anti-inflammatory, sedative, anticonvulsant, expectorant, antispasmodic, choleretic, analgesic, diuretic, wound healing, and anthelmintic actions, applied as decoctions and infusions [1], [2], [3]. The British Herbal Pharmacopoeia classifies $T$. serpyllum as a medicinal plant and is recommended for the treatment of bronchitis, bronchial catarrh, whooping cough, and acute pharyngitis [4].

At present, T. serpyllum attracts the close attention of scientists all over the world due to its pharmacological properties. In recent years, interest in the ethnobotanical, phytochemical, and pharmacological studies of the medicinal properties of $T$. serpyllum is increased [5]. The systematic studies are performing on 
the chemical composition and biological properties of T. serpyllum depending on the geographic region, climatic conditions, and growing environment, harvest season and vegetation phase. On their basis, it was determined that the essential oil and extracts of $T$. serpyllum are a promising natural resource for the pharmaceutical industry to develop and introduce the new effective herbal medicines in the traditional medicine [6], [7], [8], [9], [10], [11], [12], [13], [14], [15], [16], [17], [18].

In the world practice, it was proven that $T$. serpyllum in nature, depending on the geographic region, climatic conditions, and growing environment, is represented with some chemotypes, that is, changes in the qualitative composition and quantitative content of essential oil and the basic groups of the biologically active substances, therefore, the pharmacological properties also change [5]. Thus, the study of the chemical composition and the biological properties of T. serpyllum, depending on the territory and growing conditions, is of great importance to use this medicinal plant in the pharmaceutical industry and medicine.

The above-stated is confirmed by our previously studies of $T$. serpyllum growing in populations of Central Kazakhstan. The results of a comparative pharmacognostic study determined that $T$. serpyllum, growing in the Karaganda region (Figure 1), is represented by two chemotypes. Two herbal samples of $T$. serpyllum have an external similarity and identical diagnostic features of the anatomical structure for a leaf, stem, calyx, and corolla. In addition, significant differences were found between two chemotypes of $T$. serpyllum on the yield and composition of essential oil. The yield of essential oil from $T$. serpyllum growing in the Karkaralinsk mountainforest was $1.38 \%$. The key components are carvacrol $(37.44 \%)$, thymol $(16.26 \%)$, O-cymene $(16.11 \%)$, and $\gamma$-terpinene $(11.85 \%)$ in compliance with requirements of the State Pharmacopoeia of the Republic of Kazakhstan. The yield of essential oil from $T$. serpyllum collected in the Korenevsky forests was $0.42 \%$, the basic components are nerolidol (33.72\%), $\beta$-linalool (6.21\%), 1.8-cineole (5.92\%), and $\alpha$-terpineol $(5.40 \%)$, which does not meet the requirements State Pharmacopoeias of the Republic of Kazakhstan. The differences between two chemotypes of $T$. serpyllum by a quantitative content of the sum of flavonoids, phenol carboxylic acids, tannins, triterpene compounds, water-soluble polysaccharides, pectin substances, amino acids, and organic acids were also defined [19].

In this research, dry extracts from the aerial part of two chemotypes of $T$. serpyllum were first obtained

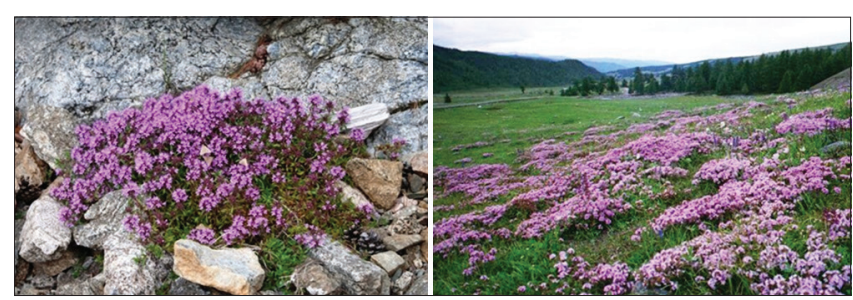

Figure 1: Thymus serpyllum L. in nature of Central Kazakhstan not by traditional methods of extraction (maceration, percolation, Soxhletapparatus), but by two-fold extraction of plant materials with $70 \%$ ethanol using ultrasound, at an ultrasonic frequency of $40 \mathrm{kHz}$. The study of antimicrobial activity and polyphenolic profiles of the obtained ultrasonic extracts was first performed. Thus, the aim of this research is to determine the possibility of using the ultrasonic extracts of two chemotypes of T. serpyllum of Central Kazakhstan as an antimicrobial agent against test strains of microorganisms.

\section{Materials and Methods}

\section{Plant material}

The aerial part of T. serpyllum L. was collected from populations of the Karaganda region of the Republic of Kazakhstan: Sample 1 in the Karkaralinsk mountain-forest (N 49 $38395^{\prime}$; E $75^{\circ} 47577^{\prime}$ ) and sample 2 in the Korenevsky forests (N 50 $21652^{\prime}$; E $74^{\circ} 33377^{\prime}$ ), in July 2016, in the full flowering phase. The botanical identification is confirmed at the Institute of Botany and Phytointroduction of the Science Committee of the Ministry of Education and Science of the Republic of Kazakhstan (conclusion on the species of plant raw materials No. 01-04/358).

\section{The obtaining of ultrasonic extracts}

Dry extracts from two samples of T. serpyllum $L$. were obtained by double extraction of air-dry raw materials (leaves, flower baskets, and thin stems) with $70 \%$ ethanol, without soaking, the ratio of raw material mass and extractant volume is $1: 20$, in an Ultrasonic Cleaner ultrasonic bath (China) with the frequency of the ultrasonic radiation ( $40 \mathrm{kHz}$, ) at room temperature $\left(20-22^{\circ} \mathrm{C}\right)$ for $30 \mathrm{~min}$. After ultrasonic treatment, the liquid extracts were filtered and the extractant was evaporated on Rotavapor ${ }^{\circledR}$ R-100 (Buchi, Switzerland) to dryness at temperature of $50^{\circ} \mathrm{C}$.

\section{LC- ultraviolet (UV)-ESI-tandem mass spectrometry (MS/MS) analysis}

High-performance liquid chromatography (HPLC) combined with a UV detector and real-time ESI-MS/MS were used to analyze the polyphenolic compounds of ultrasonic extracts. The following reagents were used in this research: acetonitrile (ACN) for HPLC ( $\geq 99$, 9\%, Sigma-Aldrich, France), formic acid (99-100\%, AnalaR NORMAPUR ${ }^{\circledR}$, VWR Chemicals, France), highly purified water was prepared with a Milli-Q (Millipore, France) water purification system. The 17 selected phenolic compounds and standards (gallic acid, caffeic acid, chlorogenic acid, ferulic acid, rosmarinic acid, catechin, epicatechin, naringin, 
rutin, luteolin-7-O-glucoside, luteolin, quercetin, apigenin, kaempferol, dihydroquercetin, myricetin, and naringenin) were purchased from Sigma-Aldrich (USA).

The analysis was performed on an "Agilent 1260 Infinity HPLC system" liquid chromatograph (Agilent Technologies, USA), equipped with G1311C 1260 Pump VL, autosampler G1329B 1260 ALS, thermostatted column compartment G1316A 1260 TCC; variable wavelength detector G1314C 1260 VWD VL+ and massspectrometer G6130A Quadrupole LC-MS/MS. Operated by Windows NT based ChemStation software was used.

Chromatographic separations were performed on a column with a "Zorbax Eclipse Plus C18" reversed-phase sorbent (150 mm × $4.6 \mathrm{~mm}, 3.5 \mu \mathrm{m}$, Agilent Technologies, USA). For separations, a gradient of mobile phase $\mathrm{A}(2.5 \%$ $(\mathrm{v} / \mathrm{v})$ formic acid in water) and mobile phase B $(2.5 \%(\mathrm{v} / \mathrm{v})$ formic acid in ACN) was used. The gradient profile was set as follows: $0.00 \mathrm{~min} 3 \% \mathrm{~B}$ eluent, $7.00 \mathrm{~min} 20 \% \mathrm{~B}$ eluent, $7.10 \mathrm{~min} 30 \%$ B eluent, $27.00 \mathrm{~min}$ 40\% B eluent, $35.00 \mathrm{~min} 50 \%$ B eluent, $35.10 \mathrm{~min} 20 \% \mathrm{~B}$ eluent, and $40.00 \mathrm{~min} 3 \% \mathrm{~B}$ eluent. The flow rate was $0.4 \mathrm{~mL} / \mathrm{min}$, the column temperature was $30^{\circ} \mathrm{C}$. The ultrasonic extracts and standards were dissolved in a mixture of solvents ACN:water $=1: 1(\mathrm{v} / \mathrm{v})$. The injection volume was $20 \mu \mathrm{L}$ for the ultrasound extracts and standards. The column effluent passed through a UV detector before arriving in the MS interface. UV detection wavelengths were $280 \mathrm{~nm}$ and $360 \mathrm{~nm}$. The electrospray ionization mass spectrometry detection was performed in negative mode with the following optimized parameters: Capillary temperature $350^{\circ} \mathrm{C}$; drying gas $\mathrm{N}_{2} 8 \mathrm{~L} / \mathrm{min}$; and nebulizer pressure 45 psi. Data gaining was performed using multiple reactions monitoring method that only monitors specific mass transitions during preset retention times.

The identification of each compound was performed by comparing their retention times to authentic standards and also confirmed by an Agilent G6130A LC-MS/MS spectrometer equipped with an electrospray ionization source. The quantitative content of phenolic compounds in ultrasonic extracts was calculated by the external standard method.

\section{Study of antimicrobial activity}

The ultrasound extracts were screened for the antibacterial and antifungal activities by microdilution method using Mueller-Hinton $(\mathrm{MH})$ broth and $\mathrm{MH}$ broth with $5 \%$ lysed sheep/horse blood for growth of non-fastidious and fastidious bacteria, respectively, or $\mathrm{MH}$ broth with $2 \%$ glucose for growth of fungi. Minimal Inhibitory Concentration (MIC) of the tested extract was evaluated for the panel of the reference microorganisms from American Type Culture Collection (ATCC), including Gram-positive bacteria (Staphylococcus aureus ATCC6538, Staphylococcus epidermidis ATCC12228, Micrococcus luteus ATCC10240, Bacillus subtilis ATCC6633, Bacillus cereus ATCC10876, Streptococcus pneumoniaeATCC49619, Streptococcus pyogenes ATCC19615, and Streptococcus mutans ATCC25175), Gram-negative bacteria (Salmonella typhimurium ATCC14028, Klebsiella pneumoniae ATCC13883, Escherichia coli ATCC25922, Proteus mirabilis ATCC12453, Pseudomonas aeruginosa ATCC9027, and Helicobacter pylori ATCC43504), and fungi (Candida albicans ATCC102231, Candida parapsilosis ATCC22019, Candida glabrata ATCC 90030, and Candida krusei ATCC 14243).

The ultrasound extracts dissolved in dimethyl sulfoxide (DMSO) were first diluted to concentration $(20 \mathrm{~g} / \mathrm{mL})$ in an appropriate broth medium recommended for bacteria or yeasts. Then, using the same media, serial two-fold dilutions were made to obtain the final concentrations of the tested extracts ranged from 20 to $0.156 \mathrm{mg} / \mathrm{mL}$. The sterile 96-well polystyrene microtitrate plates (Nunc, Denmark) were prepared by dispensing $200 \mu \mathrm{l}$ of appropriate dilution of the tested extracts in broth medium per well. The inocula were prepared with fresh microbial cultures in sterile $0.85 \% \mathrm{NaCl}$ to match the turbidity of $0.5 \mathrm{McF}$ arland standard and $2 \mu \mathrm{l}$ were added to wells to obtain final density of $1.5 \times 10^{6}$ colony forming units (CFU)/ml for bacteria and $5 \times 10^{4} \mathrm{CFU} / \mathrm{ml}$ for yeasts; CFU. After incubation $\left(35^{\circ} \mathrm{C}\right.$ for $\left.24 \mathrm{~h}\right)$, the MICs were assessed visually as the lowest concentration of the extracts showing complete growth inhibition of the reference microbial strains. Appropriate DMSO control (at a final concentration of $10 \%$ ), a positive control (containing inoculum without the tested extracts), and negative control (containing the tested extracts without inoculum) were included on each microplate [20].

The MIC of $H$. pylori was determined using two-fold microdilution method in $\mathrm{MH}$ broth with $7 \%$ of lysed horse blood at extracts concentration ranging from 20 to $0.156 \mathrm{mg} / \mathrm{mL}$ with bacterial inocula of 3 McFarland standard. After incubation at $35^{\circ} \mathrm{C}$ for $72 \mathrm{~h}$ under microaerophilic conditions $\left(5 \% \mathrm{O}_{2}, 15 \% \mathrm{CO}_{2}\right.$, and $80 \% \mathrm{~N}_{2}$ ), the growth of $H$. pylori was visualized by the addition of resazurin. The MIC endpoint was recorded as the lowest concentration of extracts that completely inhibit growth [20].

Minimal bactericidal concentration (MBC) or minimal fungicidal concentration (MFC) were obtained by subculturing $5 \mathrm{ml}$ from each well that showed through growth inhibition, from the last positive one and the growth control onto recommended agar plates. The plates were incubated at $35^{\circ}$ for $24 \mathrm{~h}$ for all microorganisms but $H$. pylori which was incubated for $72 \mathrm{~h}$ in microaerophilic conditions [20], [21]. The MBC/MFC was defined as the lowest concentration of extracts without the growth of microorganisms. The MBC/MIC ratios were calculated to determine the bactericidal or bacteriostatic effect of the tested extracts [22]. Experiment was repeated in triplicate. Representative data are presented. 


\section{Results}

\section{Results of extraction}

It was found that under similar extraction conditions, the yield of dry ultrasonic extract from T. serpyllum (sample 1) was $14.1 \pm 0.04 \%$, which significantly more than the yield of dry ultrasonic extract from $T$. serpyllum (sample 2) $6.3 \pm 0.08 \%$ ( $p<0.001$ ).

\section{Results of LC-UV-ESI-MS/MS analysis}

The phenolic profiles of the obtained ultrasonic extracts of two chemotypes of T. serpyllum and mass spectra for the identified compounds in negative ionization mode are listed in Table 1.

In total, 15 phenolic compounds were identified and quantified, five of which are phenolic acids, and ten are flavonoids. In the obtained ultrasonic extracts, we found a similarity in the qualitative composition of the phenolic compounds but determined the significant differences in the quantitative content of phenolic acids and flavonoids, except for a rosmarinic acid. The dominant polyphenolic compounds in the tested ultrasonic extracts are luteolin 7-O-glucoside with a content of 94.69 and $119.26 \mathrm{mg} / \mathrm{g}$, rosmarinic acid (32.61 and $32.62 \mathrm{mg} / \mathrm{g}$ ), naringenin (7.69 and $17.82 \mathrm{mg} / \mathrm{g}$ ), and epicatechin $(9.03$ and $11.74 \mathrm{mg} / \mathrm{g})$. The ultrasonic extract of $T$. serpyllum (sample 1) contains a relatively high amount of catechin, myricetin, quercetin, apigenin, and kaempferol. In the ultrasonic extract of $T$. serpyllum (sample 2), a relatively higher content of caffeic acid, gallic acid, chlorogenic acid, ferulic acid, epicatechin, rutin, luteolin 7-O-glucoside, naringenin, and luteolin.

\section{Research results of antimicrobial activity}

The research results in Table 2 demonstrate that the ultrasonic extracts of two chemotypes of T. serpyllum have a broad spectrum of antimicrobial activity, exhibit the bactericidal (MBC/MIC $\leq 4)$ or bacteriostatic (MBC/MIC >4) activity against all test strains.

However, the ultrasonic extract of $T$. serpyllum (sample 1) showed the maximum bactericidal activity against $H$. pylori with $\mathrm{MIC}=0.625 \mathrm{mg} / \mathrm{ml}$ and $\mathrm{MBC}=$ $1.25 \mathrm{mg} / \mathrm{ml}(\mathrm{MBC} / \mathrm{MIC}=2)$. It has a stronger bactericidal effect against 5 strains of Gram-positive bacteria of S. aureus, S. epidermidis, M. luteus, and $B$. subtilis at a concentration of $1.25-2.5 \mathrm{mg} / \mathrm{ml}(\mathrm{MBC} / \mathrm{MIC}=1)$, and causes growth inhibition of cultures of $B$. cereus at a concentration of $\mathrm{MIC}=2.5 \mathrm{mg} / \mathrm{ml}$. Furthermore, at a concentration of $1.25-2.5 \mathrm{mg} / \mathrm{ml}$ can be observed a bactericidal effect $(\mathrm{MBC} / \mathrm{MIC}=1)$ against Gramnegative strains of $K$. pneumoniae and $P$. mirabilis.

Table 1: Identification and content of phenolic compounds of ultrasound extracts two chemotypes of $T$. serpyllum $L$

\begin{tabular}{|c|c|c|c|c|c|}
\hline \multirow[t]{2}{*}{ Peak } & \multirow{2}{*}{ Retention time (min) } & \multirow[t]{2}{*}{$\mathrm{M}-\mathrm{H}^{-}(\mathrm{m} / \mathrm{z})$} & \multirow{2}{*}{ Compound identity } & \multicolumn{2}{|l|}{ Quantification (mg/g dry extract) } \\
\hline & & & & Ultrasonic extract T. serpyllum (sample 1) & Ultrasonic extract $T$. serpyllum (sample 2) \\
\hline 1 & 3.928 & 179 & Caffeic acid & ( & , \\
\hline 2 & 4.932 & 169 & Gallic acid & 3.89 & 4.18 \\
\hline 3 & 12.485 & 353 & Chlorogenic acid & 0.46 & 0.92 \\
\hline 4 & 13.089 & 289 & Catechin & 1.74 & 1.30 \\
\hline 5 & 13.945 & 289 & Epicatechin & 9.03 & 11.74 \\
\hline 6 & 14.112 & 609 & Rutin & 2.54 & 2.94 \\
\hline 7 & 14.600 & 447 & Luteolin 7-O-glucoside & 94.69 & 119.26 \\
\hline 8 & 16.299 & 193 & Ferulic acid & 2.64 & 3.03 \\
\hline 9 & 16.986 & 359 & Rosmarinic acid & 32.61 & 32.62 \\
\hline 10 & 17.448 & 317 & Myricetin & 3.08 & 2.95 \\
\hline 11 & 22.303 & 301 & Quercetin & 0.65 & 0.47 \\
\hline 12 & 25.267 & 271 & Naringenin & 7.69 & 17.82 \\
\hline 13 & 27.350 & 269 & Apigenin & 1.16 & 0.72 \\
\hline 14 & 28.350 & 285 & Luteolin & 0.87 & 1.30 \\
\hline 15 & 28.806 & 285 & Kaempferol & 0.53 & 0.19 \\
\hline
\end{tabular}

Table 2: Research results of antimicrobial activity of ultrasonic extracts of two chemotypes of $T$. serpyllum $L$

\begin{tabular}{|c|c|c|c|c|c|c|}
\hline \multirow[t]{2}{*}{ Microorganism } & \multicolumn{3}{|c|}{ Ultrasonic extract $T$. serpyllum (sample 1) } & \multicolumn{3}{|c|}{ Ultrasonic extract $T$. serpyllum (sample 2) } \\
\hline & $\mathrm{MIC}(\mathrm{mg} / \mathrm{ml})$ & $\mathrm{MBC}(\mathrm{mg} / \mathrm{ml})$ & $\mathrm{MBC} / \mathrm{MIC}$ ratio & $\mathrm{MIC}(\mathrm{mg} / \mathrm{ml})$ & $\mathrm{MBC}(\mathrm{mg} / \mathrm{ml})$ & MBC/MIC ratio \\
\hline \multicolumn{7}{|l|}{ Gram-positive bacteria } \\
\hline Staphylococcus aureus & 1.25 & 1.25 & 1 & 2.5 & 2.5 & 1 \\
\hline Staphylococcus epidermidis & 1.25 & 1.25 & 1 & 1.25 & 1.25 & 1 \\
\hline Micrococcus luteus & 2.5 & 2.5 & 1 & 2.5 & 5 & 2 \\
\hline Bacillus subtilis & 1.25 & 1.25 & 1 & 1.25 & 5 & 4 \\
\hline Bacillus cereus & 2.5 & $>20$ & $>8$ & 2.5 & $>20$ & $>8$ \\
\hline Streptococcus pneumoniae & 5 & 10 & 2 & 2.5 & 5 & 2 \\
\hline Streptococcus pyogenes & 5 & 10 & 2 & 2.5 & 10 & 4 \\
\hline Streptococcus mutans & 5 & 20 & 4 & 5 & 5 & 1 \\
\hline \multicolumn{7}{|l|}{ Gram-negative bacteria } \\
\hline Salmonella typhimurium & 10 & 10 & 1 & 5 & 5 & 1 \\
\hline Klebsiella pneumoniae & 1.25 & 1.25 & 1 & 1.25 & 1.25 & 1 \\
\hline Proteus mirabilis & 2.5 & 2.5 & 1 & 2.5 & 2.5 & 1 \\
\hline Escherichia coli & 10 & 10 & 1 & 5 & 5 & 1 \\
\hline Pseudomonas aeruginosa & 5 & 10 & 2 & 5 & 10 & 2 \\
\hline Helicobacter pylori & 0.625 & 1.25 & 2 & 0.0625 & 0.250 & 4 \\
\hline \multicolumn{7}{|l|}{ Yeasts } \\
\hline Candida albicans & 10 & 10 & 1 & 2.5 & 10 & 4 \\
\hline Candida parapsilosis & 10 & 10 & 1 & 5 & 10 & 2 \\
\hline Candida glabrata & 10 & $>20$ & $>2$ & 5 & 10 & 2 \\
\hline Candida krusei & 10 & 10 & 1 & 5 & 10 & 2 \\
\hline
\end{tabular}


The ultrasonic extract of T. serpyllum (sample 2) showed the maximum bactericidal activity against H. pylori with the lowest MIC $=0.0625 \mathrm{mg} / \mathrm{ml}$ and $\mathrm{MBC}$ $=0.250 \mathrm{mg} / \mathrm{ml}(\mathrm{MBC} / \mathrm{MIC}=4)$. This ultrasound extract has stronger bactericidal activity against only 2 strains of Gram-positive bacteria of $S$. aureus and $S$. epidermidis at a concentration of $1.25-2.5 \mathrm{mg} / \mathrm{ml}(\mathrm{MBC} / \mathrm{MIC}=$ 1 ), while inhibiting the growth of cultures of 5 strains of M. luteus, B. subtilis, B. cereus, S. pneumoniae, and $S$. pyogenes at a concentration of $1.25-2.5 \mathrm{mg} /$ $\mathrm{ml}$. Furthermore, at a concentration of $1.25-2.5 \mathrm{mg} /$ $\mathrm{ml}$, it has a bactericidal effect $(\mathrm{MBC} / \mathrm{MIC}=1)$ against 2 strains of gram-negative bacteria of $K$. pneumoniae and $P$. mirabilis. In addition, at a concentration of 2.5 $\mathrm{mg} / \mathrm{ml}$, it causes growth inhibition of the culture of $C$. albicans fungus.

\section{Discussion}

Our results confirm that $T$. serpyllum $L$. in nature, depending on the geographic region, climatic conditions, and growing environment, is represented by some chemotypes, their composition, quantitative content of the biologically active substances, and biological properties, in particular, antimicrobial action is differ.

In addition, the method of extracting of the biologically active substances from plant raw materials of $T$. serpyllum is important. The basic biologically active substances of $T$. serpyllum, besides an essential oil, are phenolic compounds. These secondary metabolites play an important biological role and have a wide range of pharmacological properties, including antimicrobial action [23], [24]. The content of polyphenols and their structure (number and position of the hydroxyl groups in a molecule) significantly influence on the pharmacological properties of the medicinal plants. Water, methanol, and ethanol are the most commonly used solvents to extract polyphenols from plant materials. As a rule, the standard methods of extraction are used to extract polyphenols (maceration, percolation, and Soxhlet apparatus). Leaves of $T$. serpyllum (Morocco) were extracted with $90 \%$ ethanol for 4 days at room temperature. The resulting extract has antibacterial activity against Listeria monocytogenes (MIC $=2.15 \mathrm{mg} / \mathrm{ml}$ ) and also inhibits the growth of $S$. aureus, E. coli, Enterococcus faecalis, K. pneumoniae, Enterobacter cloacae, and Acinetobacter baumannii [25]. The buffered methanol leaf extract of $T$. serpyllum growing in Yemen has antimicrobial activity against Listeria monocytogenes, S. aureus, and B. cereus with $\mathrm{MIC}=660-1320 \mathrm{mg} / \mathrm{l}$. At a maximum concentration of $2640 \mathrm{mg} / \mathrm{l}$, it does not exhibit an antimicrobial action against $E$. coli and Salmonella infantis [26]. Fresh leaves of T. serpyllum collected at the edge of a pine forest (Baymaky village, Bilohirya district, Khmelnytsky region, Ukraine) were washed, weighed, ground, and homogenized in $96 \%$ ethanol (1:19 ratio) at room temperature. The resulting extract exhibits an antimicrobial action against Acinetobacter baumannii, the average diameter of the zone of inhibition is $10.45 \pm 0.81 \mathrm{~mm}$ [27]. The plant $T$. serpyllum used in this research was obtained commercially (Aboca, SpA, S. Sepolcro, Arezzo, Italy). The plant was extracted with distilled water (aqueous extract) or 95\% ethanol (ethanol extract) at room temperature for $24 \mathrm{~h}$. The extracts have an antibacterial effect against the control and eleven clinical strains of $H$. pylori, for the aqueous extract of MIC $=1.25-10 \mathrm{mg} / \mathrm{mL}$ and for ethanol extract o $\mathrm{MIC}=1.25-2.5 \mathrm{mg} / \mathrm{mL}[28]$

In this research, the sum of the polyphenolic compounds from the dry aerial part of two chemotypes of $T$. serpyllum was extracted by not traditional methods of extraction (maceration, percolation, and Soxhlet apparatus) but using ultrasound. A method for obtaining of dry extract from $T$. serpyllum, due to the use of the ultrasonic extraction, is characterized by high productivity of the technological process, low consumption of extractant, elimination of labor-intensive and time-consuming procedures, which makes it affordable, rational, and economical. This method can find its application in the pharmaceutical industry to produce new medicines with an antimicrobial action of the plant origin [29], [30].

The obtained ultrasonic extracts of two chemotypes of $T$. serpyllum growing in the territory of Central Kazakhstan have a wide spectrum of antimicrobial activity, exhibit the bactericidal or bacteriostatic activity against all tested bacteria and fungi at a concentration of 0.0625 to $20 \mathrm{mg} / \mathrm{ml}$, but differ in their effect against the test strains of microorganisms.

An ultrasonic extract of creeping thyme collected in the Karkaralinsk mountain-forest showed maximum bacteriostatic activity against $H$. pylori with $\mathrm{MIC}=0.625 \mathrm{mg} / \mathrm{ml}$ and bactericidal at a concentration of $1.25 \mathrm{mg} / \mathrm{ml}$. It has a stronger bactericidal effect against 5 strains of gram-positive bacteria of $S$. aureus, $S$. epidermidis, $M$. luteus, and $B$. subtilis at a concentration of $1.25-2.5 \mathrm{mg} / \mathrm{ml}$, and only bacteriostatic action against $B$. cereus $\mathrm{MIC}=2.5 \mathrm{mg} / \mathrm{ml}$. Furthermore, at a concentration of $1.25-2.5 \mathrm{mg} / \mathrm{ml}$, it exhibits a bactericidal effect against Gram-negative strains of K. pneumoniae and P. mirabilis.

For an ultrasonic extract of $T$. serpyllum collected in the Korenevsky forests, the maximum bacteriostatic and bactericidal activity against $H$. pylori was defined with the lowest $\mathrm{MIC}=0.0625 \mathrm{mg} / \mathrm{ml}$ and $\mathrm{MBC}=0.250$ $\mathrm{mg} / \mathrm{ml}$. This ultrasonic extract demonstrates a stronger bactericidal activity against only 2 strains of grampositive bacteria of $S$. aureus and $S$. epidermidis at a concentration of $1.25-2.5 \mathrm{mg} / \mathrm{ml}(\mathrm{MBC} / \mathrm{MIC}=1)$, but at the same concentration inhibits the growth of cultures of 5 strains M. luteus, B. subtilis, B. cereus, S. pneumoniae, and $S$. pyogenes. Furthermore, at a concentration of $1.25-2.5 \mathrm{mg} / \mathrm{ml}$, it has a bactericidal effect $(\mathrm{MBC} /$ 
MIC = 1) against 2 strains of Gram-negative bacteria of $K$. pneumoniae and $P$. mirabilis. In addition, at a concentration of $2.5 \mathrm{mg} / \mathrm{ml}$, it causes growth retardation of the culture of the fungus $C$. albicans.

There are also differences in the bactericidal and bacteriostatic effects of the tested ultrasonic extracts against the tested bacteria and fungi at a concentration of $5-20 \mathrm{mg} / \mathrm{ml}$.

It can be explained by the difference in the quantitative content of the identified phenolic acids and flavonoids. The dominant phenolic compounds in the studied ultrasonic extracts are luteolin 7-O-glucoside with a content of 94.69 and $119.26 \mathrm{mg} / \mathrm{g}$, rosmarinic acid (32.61 and $32.62 \mathrm{mg} / \mathrm{g}$ ), naringenin (7.69 and $17.82 \mathrm{mg} / \mathrm{g}$ ), and epicatechin (9.03 and $11.74 \mathrm{mg} / \mathrm{g}$ ). The ultrasonic extract of $T$. serpyllum collected in the Karkaralinsk mountain-forest, contains a relatively high amount of catechin, myricetin, quercetin, apigenin, and kaempferol. In an ultrasonic extract of $T$. serpyllum collected in the Korenevsky forests, a relatively higher content of caffeic acid, gallic acid, chlorogenic acid, ferulic acid, epicatechin, rutin, luteolin 7-O-glucoside, naringenin, and luteolin was determined. Research of the composition of the phenolic compounds by ultrasonic extracts of two chemotypes of $T$. serpyllum L. of Central Kazakhstan was first performed. Our obtained results proved that depending on the territory and growing conditions in nature, the composition and quantitative content of biologically active substances of $T$. serpyllum $\mathrm{L}$. change. The obtained ultrasonic extracts have significant differences in the qualitative composition of phenolic compounds and the quantitative content of phenolic acids and flavonoids, from the data previously published in the world literature [24], [31], [32], [33], [34], [35].

Thus, it was first established that ultrasonic extracts of the two chemotypes of $T$. serpyllum growing in the territory of Central Kazakhstan have a wide spectrum of antimicrobial activity, exhibit the bactericidal or bacteriostatic activity against all tested bacteria and fungi at a concentration of $0.0625-20 \mathrm{mg} / \mathrm{ml}$, but differ in their effect against test strains of microorganisms. Since, they contain various amounts of the identified phenolic acids and flavonoids, except for rosmarinic acid.

\section{Conclusions}

Ultrasonic extracts of two chemotypes of $T$. serpyllum L. of Central Kazakhstan can be considered as a potential drug with a wide spectrum of antimicrobial activity. The results of chromatographic analysis will be used for standardization of a drug.

\section{References}

1. Republic of Kazakhstan. State Pharmacopoeia of the Republic of Kazakhstan. Vol. 2. Astana: Republic of Kazakhstan; 2009. p. 802.

2. State Pharmacopoeia of the USSR. Vol. 6. Moscow: 1990. p. 60

3. State Pharmacopoeia of Ukraine. State Prize of the Ukrainian Scientific Pharmacopoeial Center of Legal Education. Vol. 3. Kharkiv: State Pharmacopoeia of Ukraine; 2014. p. 487-490.

4. The British Pharmacopoeia. Commission Secretariat of the Medicines and Healthcare Products Regulatory Agency. London, United Kingdom: The British Pharmacopoeia; 2015.

5. Jaric S, Mitrovic M, Pavlovic P. Review of ethnobotanical, phytochemical, and pharmacological study of Thymus serpyllum $\mathrm{L}$. J Evid Based Complementary Altern Med. 2015;2015:1-10. PMid:26265920

6. Jaric S, Mitrovic M, Karadzic B, Kostić O, Djurjević L, Pavlović M et al. Plant resources used in Serbian medieval medicine. Ethnobot Ethnomed. 2014;61:1359-79.

7. Quave CL, Pardo-de-Santayana M, Pieroni A. Medica ethnobotany in Europe: from field ethnography to a more culturally sensitive evidence-based cam? Evid Based Complement Alternat Med. 2012;2012:156846.

PMid:22899952

8. Mati E, de Boer H. Ethnobotany and trade of medicinal plants in the Qaysari Market, Kurdish Autonomous Region, Iraq. J Ethnopharmacol. 2011;133:490-510.

PMid:20965241

9. Pieroni A, Rexhepi B, Nedelcheva A, Hajdari A. One century later: The folk botanical knowledge of the last remaining Albanians of the upper Reka Valley, Mount Korab, Western Macedonia. J Ethnobiol Ethnomed. 2013;9:22.

10. Rexhepi B, Mustafa B, Hajdari A, Rushidi-Rexhepi J, Quave CL, Pieroni A. Traditional medicinal plant knowledge among Albanians, Macedonians and Gorani in the Sharr Mountains (Republic of Macedonia). Genet Resour Crop Evol. 2013;60:2055-80.

11. Kayani S, Ahmad M, Zafar M, Sultana S, Khan MP, Ashraf MA et al. Ethnobotanical uses of medicinal plants for respiratory disorders among the inhabitants of Gallies-Abbottabad, Northern Pakistan. J Ethnopharmacol. 2014;156:47-60. PMid:25153021

12. Mustafa B, Hajdari A, Krasniqi F, Hoxha E, Ademi H, Quave CL, et al. Medical ethnobotany of the Albanian Alps in Kosovo. $J$ Ethnobiol Ethnomed. 2012;8:6. PMid:22284581

13. Mustafa B, Hajdari A, Pajazita Q, Syla B, Quave CL, Pieroni A An ethnobotanical survey of the Gollak region, Kosovo. Genet Resour Crop Evol. 2012;59:739-54.

14. Mustafa B, Hajdari A, Pieroni A, Pulaj B, Koro X, Quave CL. A cross-cultural comparison of folk plant uses among Albanians, Bosniaks, Gorani and Turks living in south Kosovo. J Ethnobiol Ethnomed. 2015;11:39.

PMid:25964167

15. Gairola S, Sharma J, Bedi YS. A cross-cultural analysis of Jammu, Kashmir and Ladakh (India) medicinal plant use. $J$ Ethnopharmacol. 2014;155(2):925-86. PMid:24952280

16. Kozuharova E, Lebanova H, Getov I, Benbassat N, Napier J. Descriptive study of contemporary status of the traditional knowledge onmedicinal plants in Bulgaria. Afr J Pharm Pharmacol. 2013;7(5):185-98.

17. Dei Cas L, Pugni F, Fico G. Tradition of use on medicinal species 
in Valfurva (Sondrio, Italy). J Ethnopharmacol. 2015;163:113-34.

18. Carrio E, Rigat M, Garnatje T, Mayans M, Parada M, Valles J. Plant ethnoveterinary practices in two pyrenean territories of Catalonia (Iberian Peninsula) and in two areas of the balearic islands and comparison with ethnobotanical uses in humanmedicine. Evid Based Complement Alternat Med. 2012;2012:896295.

19. Orazbaeva $P Z$, Ishmuratova $M Y$, Ivasenko $S A$, Marchenko $A B$, Losseva IV. Comparative pharmacognostic study of two chemotypes of Thymus serpyllum L. of Central Kazakhstan. Pharm Kazakhstan. 2018;10(207):42-7.

20. Tejchman W, Korona-Glowniak I, Malm A, Zylewski M, Suder P. Antibacterial properties of 5-substituted derivatives of rhodanine3-carboxyalkyl acids. Med Chem Res. 2017;26(6):1316-24. PMid:28515623

21. Malm A, Glowniak-Lipa A, Korona-Glowniak I, Baj T. AntiHelicobacter pylori activity in vitro of chamomile flowers, coneflower herbs, peppermint leaves and thyme herbs a preliminary report. Curr Issues Pharm Med Sci. 2015;28(1):30-2.

22. French GL. Bactericidal agents in the treatment of MRSA infections--the potential role of daptomycin. J Antimicrob Chemother. 2006;58(6):1107-17. PMid: 17040922

23. Aziz S. Studies on the chemical constituents of Thymus serpyllum. Turk J Chem. 2008;32:605-14.

24. Boros B, Jakabova S, Dornyei A, Horvath G, Pluhar Z, Kilar F, et al. Determination of polyphenolic compounds by liquid chromatography-mass spectrometry in Thymus species. J Chromatog A. 2010;1217(51):7972-80. PMid:20692666

25. Bayoub K, Baibai T, Mountassif D, Retmane A, Soukri A. Antibacterial activities of the crude ethanol extracts of medicinal plants against Listeria monocytogenes and some other pathogenic strains. Afr J Biotechnol. 2010;9(27):4251-8.

26. Alzoreky NS, Nakahara K. Antibacterial activity of extracts from some edible plants commonly consumed in Asia. Int $\mathrm{J}$ Food Microbiol. 2003;80(3):223-30.

PMid:12423924

27. Honcharenko V, Tkachenko H, Nachychko V, Prokopiv A,
Osadowski Z. Antibacterial properties of ethanolic extracts obtained from leaves of some Thymus L. (Lamiaceae) representatives against Acinetobacter baumannii. Agrobiodiversity Improv Nutr Health Life Qual. 2019;3:14-24.

28. Nostro A, Cellini L, Di Bartolomeo S, Di Campli E, Grande R, Cannatelli MA, et al. Antibacterial effect of plant extracts against Helicobacter pylori. Phytother Res. 2005;19(3):198-202.

PMid:15934015

29. Orazbaeva PZ, Shakarimova KK, Ivasenko SA, Akhmetova SB, Losseva IV. Patent RK No. 34245 for an Invention dated 26.03.2020. A Method of Obtaining an Ultrasonic Extract from Creeping Thyme (Thymus serpyllum L.), which has an Antibacterial Effect against Helicobacter pylori; 2020.

30. Orazbaeva PZ, Shakarimova KK, Ivasenko SA, Akhmetova SB, Loseva IV. A Positive Decision on the Grant of a Eurasian Patent Dated 06.04.2020 under Application No. 201800259/28. A Method of Obtaining an Ultrasonic Extract from Creeping Thyme (Thymus serpyllum L.), which has an Antibacterial Effect against Helicobacter pylori; 2020.

31. Sonmezdag AS, Kelebek H, Selli S. Characterization of aromaactive and phenolic profiles of wild thyme (Thymus serpyllum) by GC-MS-Olfactometry and LC-ESI-MS/MS. Food Sci Technol. 2016;53(4):1957-65. PMid:27413222

32. Pereira OR, Peres AM, Silva AM, Domingues MR, Cardoso SM Simultaneous characterization and quantification of phenolic compounds in Thymus $x$ citriodorus using a validated HPLC-UV and ESI-MS combined method. Food Res Int. 2013;54:1773-80.

33. Varga E, Bardocz A, Belak A, Maraz A, Boros B, Felinger A, et al. Antimicrobial activity and chemical composition of thyme essential oils and the polyphenolic content of different Thymus extracts. Farmacia. 2015;63:357-61.

34. Cakmakçi E, Deveoglu O, Muhammed A, Fouad A, Torgan E, Karadag R. HPLC-DAD analysis of Thymus serpyllum based natural pigments and investigation of their antimicrobial properties. Pigment Resin Technol. 2014;43(1):19-25.

35. Berdowska I, Zielinski B, Fecka I, Kulbacka J, Saczko J, Gamian A. Cytotoxic impact of phenolics from Lamiaceae species on human breast cancer cells. Food Chem. 2013;141(2):1313-21. 